\title{
MoBI, Sistem Informasi berbasis Android
}

\author{
Baktiar Krisna Mukti Nugroho' ${ }^{1}$, Handoko ${ }^{2}$, Hartanto Kusuma Wardana ${ }^{3}$ \\ Fakultas Teknik Elektronika dan Komputer, \\ Universitas Kristen Satya Wacana, Salatiga \\ 1bakrimuno@gmail.com, ${ }^{2 h}$ andoko@uksw.edu, ${ }^{3 h}$ artanto.kusuma@staff.uksw.edu
}

\begin{abstract}
Ringkasan
PT Tripilar Betonmas merupakan perusahaan yang bergerak di bidang industri manufaktur atap gelombang asbes dan silica board. Pelaporan data yang kurang fleksibel menjadi masalah tersendiri pada perusahaan ini, di antaranya untuk melihat laporan masih menggunakan aplikasi desktop. Hal ini mengurangi fleksibelitas dan mobilitas untuk melihat laporan jika berada di luar lingkungan perusahaan. Di sisi lain, Android adalah sistem operasi yang paling banyak digunakan oleh pengguna smartphone seluruh dunia karena memiliki beberapa kelebihan di antaranya, memiliki banyak aplikasi yang dapat digunakan secara gratis, banyak library yang disediakan dan bersifat open source sehingga mudah untuk dikembangkan. Aplikasi Android dirancang dengan tujuan untuk mengatasi kekurangan aplikasi perusahaan dalam hal fleksibelitas dan mobilitas untuk melihat laporan. Dengan aplikasi Android ini, user dapat melihat informasi perusahaan walaupun berada di luar lingkungan perusahaan. Aplikasi Android ini dilengkapi dengan autentikasi user dengan Firebase, dapat menampilkan informasi penjualan, produksi dan barang rusak berupa grafik. Pada hari kerja pengguna akan menerima notifikasi penjualan per hari yang sudah dicapai setiap jam. Aplikasi ini dapat digunakan pada sistem operasi Jelly Bean hingga Oreo. Selain itu aplikasi ini dilengkapi dengan 3 autentikasi untuk menjaga keamanan data perusahaan yang terdiri dari autentikasi aplikasi mobile, webservice dan database.
\end{abstract}

Kata kunci: Android, Webservice, Database dan Aplikasi Mobile

\section{Pendahuluan}

PT Tripilar Betonmas merupakan perusahaan yang bergerak di bidang industri manufaktur atap gelombang Asbes dan Silica Board. Pelaporan data yang kurang fleksibel menjadi masalah tersendiri dalam perusahaan tersebut karena menggunakan aplikasi desktop.Aplikasi desktop memiliki keterbatasan yaitu mobilitas untuk melihat laporan jika berada di luar lingkungan kantor.

Berdasarkan permasalahan di atas, dirancang sebuah sistem untuk menampilkan laporan omzet, penjualan dan produksi. Aplikasi mobile berbasis Android dirancang untuk dapat berkomunikasi dengan database melalui webservice. Aplikasi mobile ini sebagai pelengkap aplikasi desktop dan pengganti aplikasi web yang sudah ada serta menjadi solusi dari masalah keterbatasaan akses yang banyak dipengaruhi oleh faktor jarak maupun kemudahan akses database, sehingga dapat meningkatkan produktivitas perusahaan.

Business Intelligence (BI) adalah sekumpulan teknik dan alat untuk mentransformasi data mentah menjadi informasi yang berguna dan bermakna untuk tujuan analisis bisnis. Teknologi BI dapat menangani data yang tak terstruktur dalam jumlah yang sangat besar untuk membantu mengidentifikasi, mengembangkan, dan selain itu membuat kesempatan 
strategi bisnis yang baru. Tujuan dari BI yaitu untuk memudahkan interpretasi dari jumlah data yang besar tersebut.

Aplikasi mobile berbasis Android ini memiliki keunggulan dibandingkan aplikasi sejenis :

Tabel 1. Perbandingan dengan aplikasi sejenis

\begin{tabular}{|c|c|c|}
\hline Keterangan & Aplikasi yang dirancang & Aplikasi sejenis (FastBudget) \\
\hline Data & $\begin{array}{c}\text { Data rill berdasarkan database yang ada di } \\
\text { perusahaan }\end{array}$ & $\begin{array}{c}\text { Data masih bersifat lokal pada } \\
\text { aplikasi }\end{array}$ \\
\hline Keamanan & $\begin{array}{l}\text { Memerlukan } 3 \text { autentikasi untuk mengakses data } \\
\text { yang tersimpan (aplikasi, webservice dan database) }\end{array}$ & $\begin{array}{c}\text { Tidak ada autentikasi untuk } \\
\text { mengakses data yang tersimpan }\end{array}$ \\
\hline
\end{tabular}

\section{Perancangan Sistem}

Pada bagian ini dijelaskan mengenai perancangan sistem yang secara umum dapat dilihat pada Gambar 1.

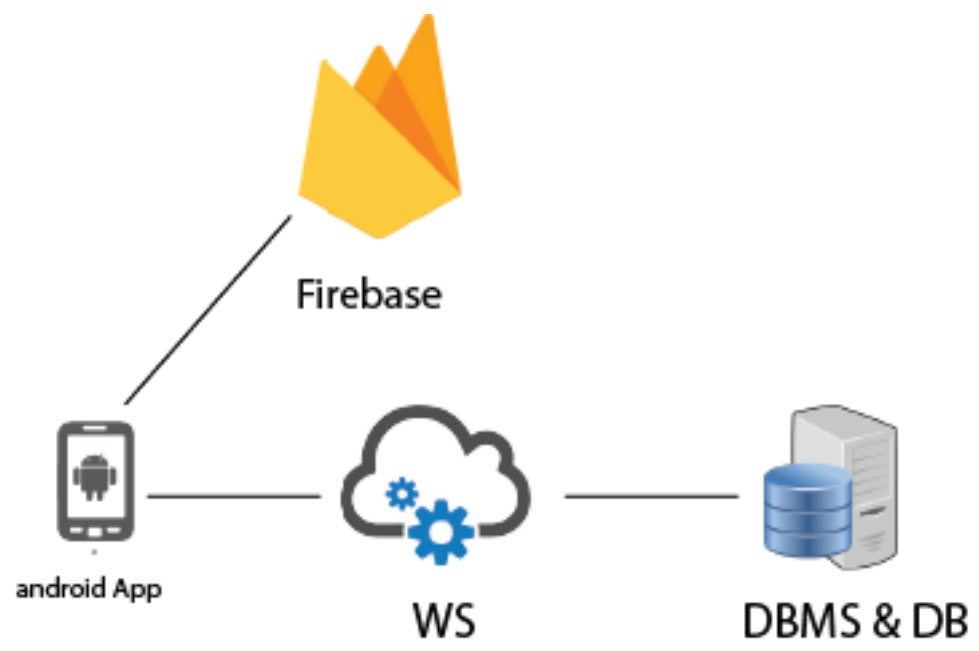

Gambar 1. Diagram Sistem

Aplikasi mobile dirancang menggunakan framework Android Studio. Aplikasi mobile berbasis Android bekerja melalui Internet untuk mengakses data pada Firebase untuk proses login. Setelah berhasil login maka aplikasi akan mengakses web service ketika menampilkan report. Selanjutnya web service akan mengakses database dengan mengirimkan query. Database Management System (DBMS) akan mengirim dataset, hasilnya akan diubah dalam format JSON pada webservice dan dikirimkan ke aplikasi.

Aplikasi Android ini memiliki user interface yang terdiri dari beberapa bagian utama di antaranya, login activity dan function menu activity

1. Login Activity berfungsi untuk keamanan aplikasi supaya tidak semua user dapat mengakses aplikasi tersebut, hanya user yang memiliki hak akses yang dapat mengakses aplikasi tersebut

2. Function Menu Activity berfungsi untuk pengambilan data ke database. 


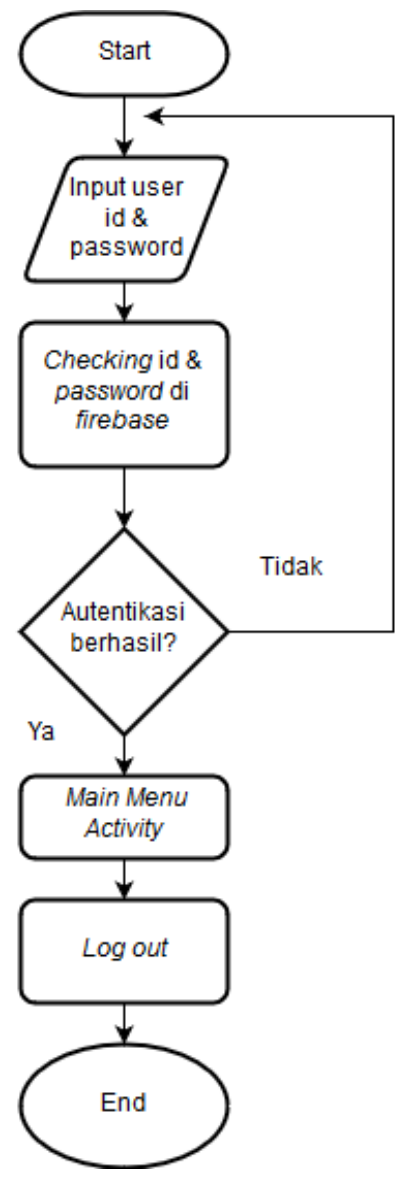

(a)

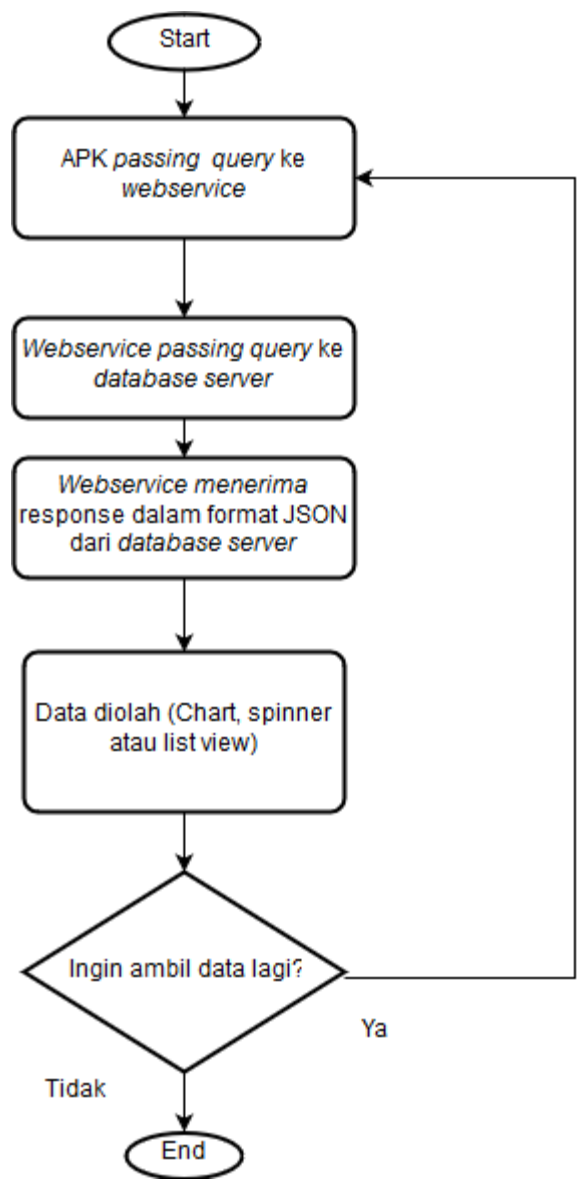

(b)

Gambar 2. a. Diagram Alir Login Activity b. Diagram Alir Pengambilan Data

Login activity akan muncul ketika pertama kali aplikasi mobile dijalankan. User memasukkan autentikasi id dan password pada activity ini. Selanjutnya id dan password yang sudah dimasukkan akan diperiksa di Firebase. Setelah berhasil diperiksa aplikasi mobile akan berpindah ke halaman menu activity (Gambar 2.a).

Sedangkan pada proses pengambilan data, aplikasi mobile passing query sesuai kebutuhan ke webservice. Selanjutnya webservice passing query ke database server. Setelah passing query, webservice akan menerima respon dari database server dan respon tersebut dipassing kembali ke aplikasi mobile untuk diolah sesuai fungsinya (Gambar 2.b). 
Web service digunakan untuk melakukan pertukaran data antar aplikasi atau sistem dan melakukan pertukaran data antara database dengan mobile app. Web Service yang digunakan pada makalah ini dibagi menjadi tiga fungsi yaitu mengunduh gambar, menghapus gambar dan mengambil data.

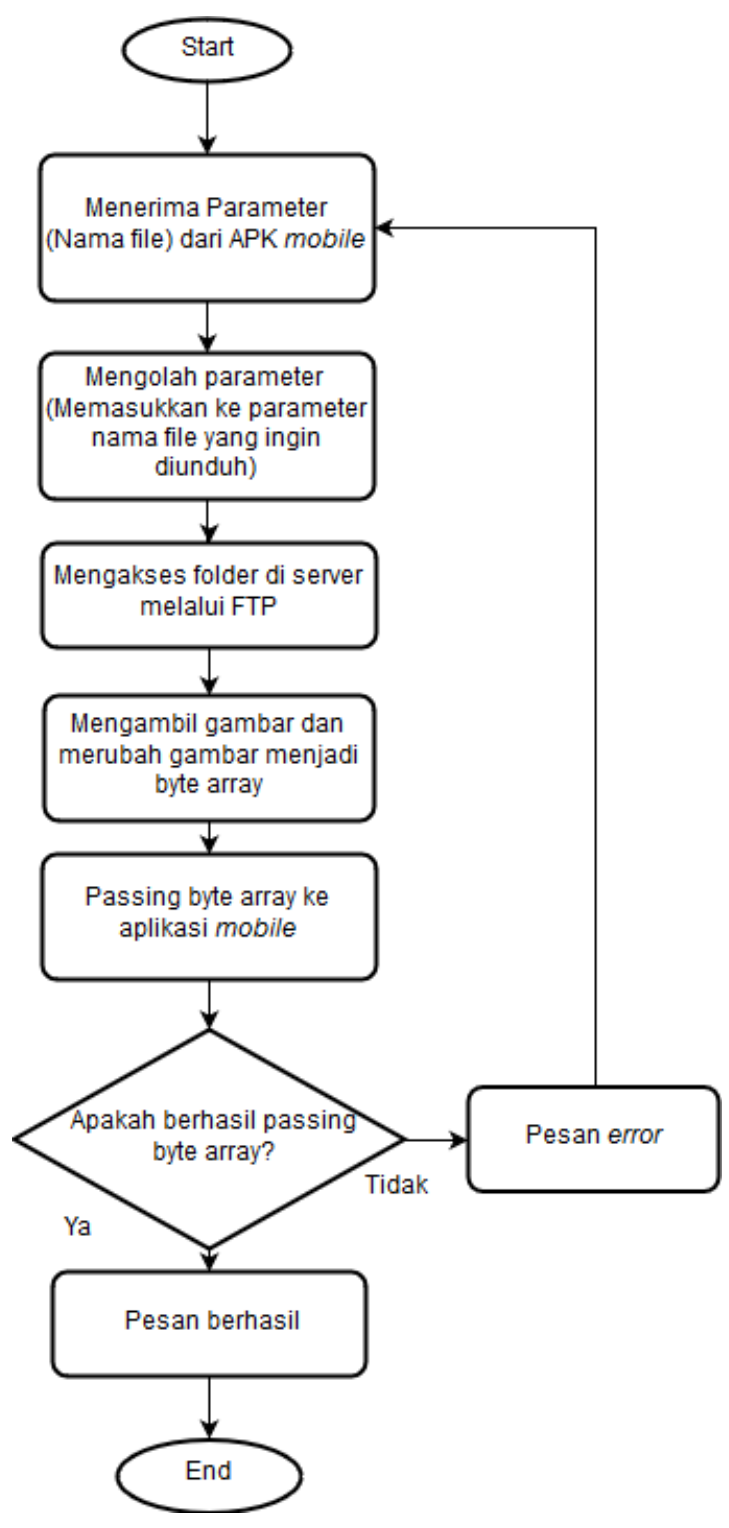

(a)

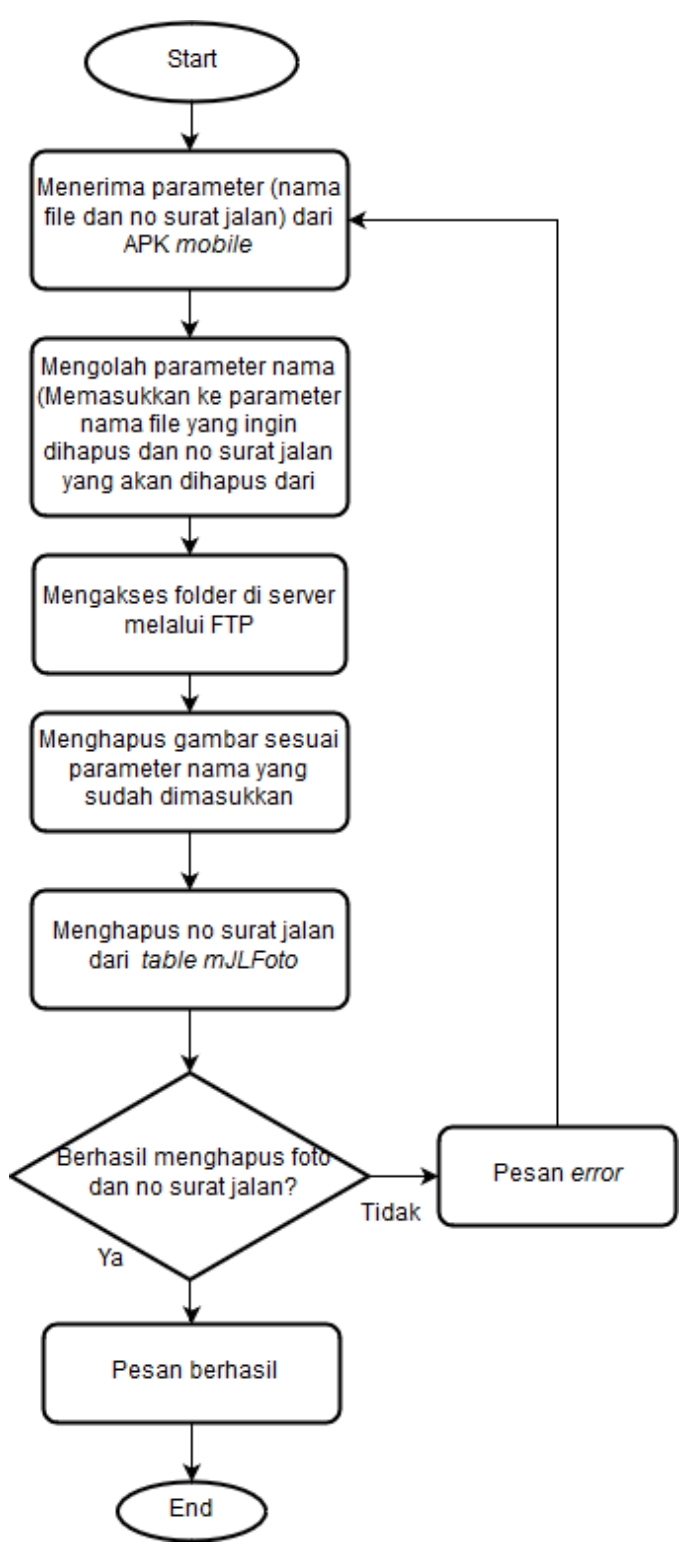

(b)

Gambar 3. a. Diagram Alir Mengunduh Gambar b. Diagram Alir Menghapus Gambar

Pada proses mengunduh gambar melalui webservice (Gambar 3.a), webservice menerima parameter nama file yang ingin diunduh. Selanjutnya webservice mengakses folder di server melalui FTP dan mengambil gambar sesuai parameter. Setelah itu gambar diubah menjadi byte array dan dikirimkan ke aplikasi mobile. Sedangkan pada Gambar 3.b proses menghapus gambar pada webservice, webservice menerima parameter nama file yang ingin dihapus. Selanjutnya webservice mengakses folder melalui FTP dan menghapus gambar sesuai 
parameter. Setelah itu webservice passing query ke database server untuk menghapus data sesuai parameter. Aplikasi mobile akan menerima respon setelah semua fungsi dijalankan dari webservice.

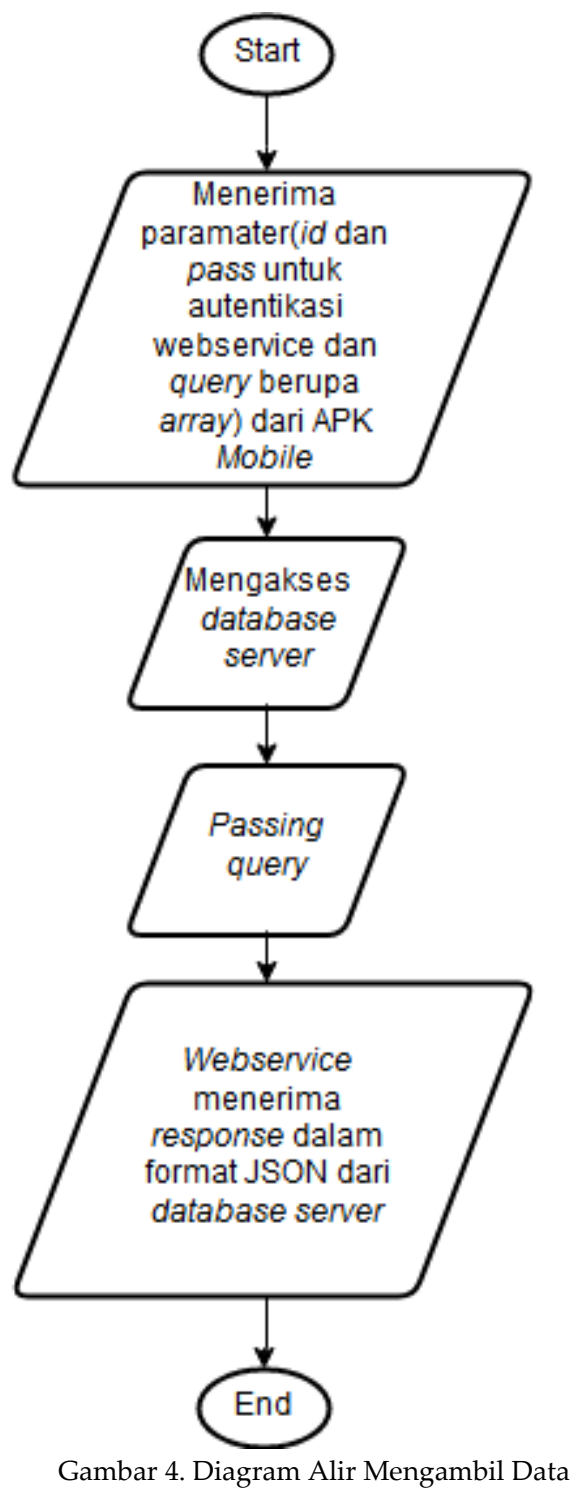

Pada Gambar 4 proses mengambil data pada webservice, webservice akan menerima parameter id dan password untuk proses autentikasi pada webservice dan query berupa array. Selanjutnya webservice akan mengakses database server dan passing query sesuai parameter yang diterima. Setelah itu webservice akan menerima respon dari database dan mengirimkannya ke aplikasi mobile.

Database yang digunakan makalah ini dibagi menjadi dua bagian yaitu dengan Firebase dan Microsoft SQL Server. Firebase digunakan untuk menyimpan data user yang digunakan untuk proses autentikasi ketika masuk aplikasi Android sedangkan Microsoft SQL Server digunakan untuk menyimpan informasi perusahaan. Gambar 5.a menunjukkan struktur data 
pada Firebase, sedangkan Gambar 5.b menunjukkan rancangan database user dalam bentuk tabel.

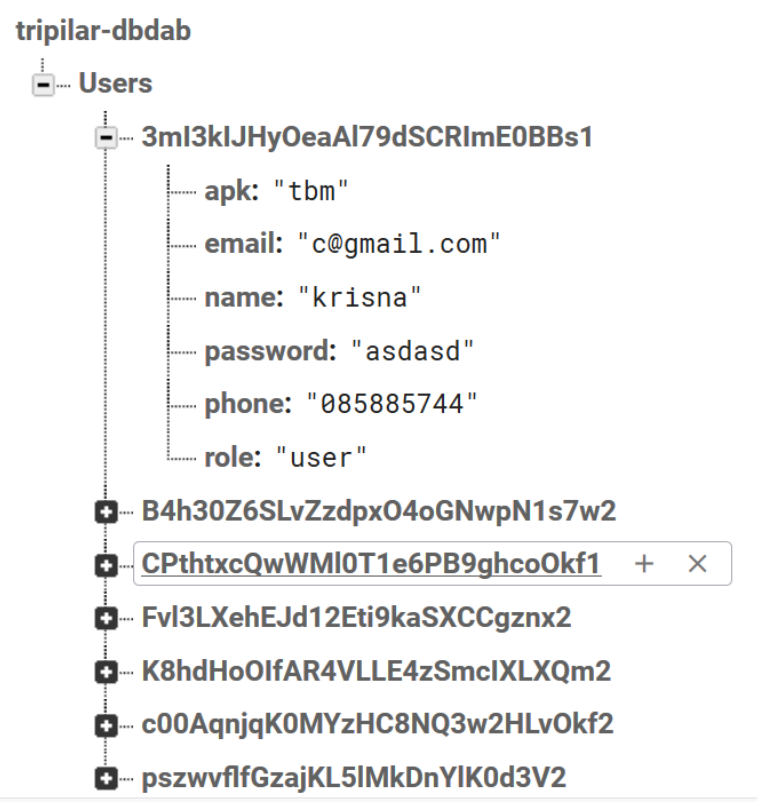

(a)

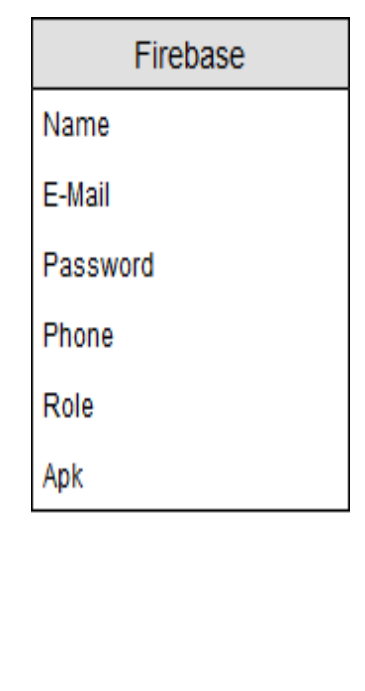

(b)

Gambar 5. a. Rancangan pada Firebase b. Rancangan Database User

Database Microsoft SQL Server digunakan untuk menyimpan data perusahaan yang meliputi penjualan, retur, produksi dan barang reject. Gambar 6 merupakan ERD (Entity Relationship Diagram) database dan tidak semua atribut ditulis, hanya atribut yang digunakan pada makalah ini saja. 


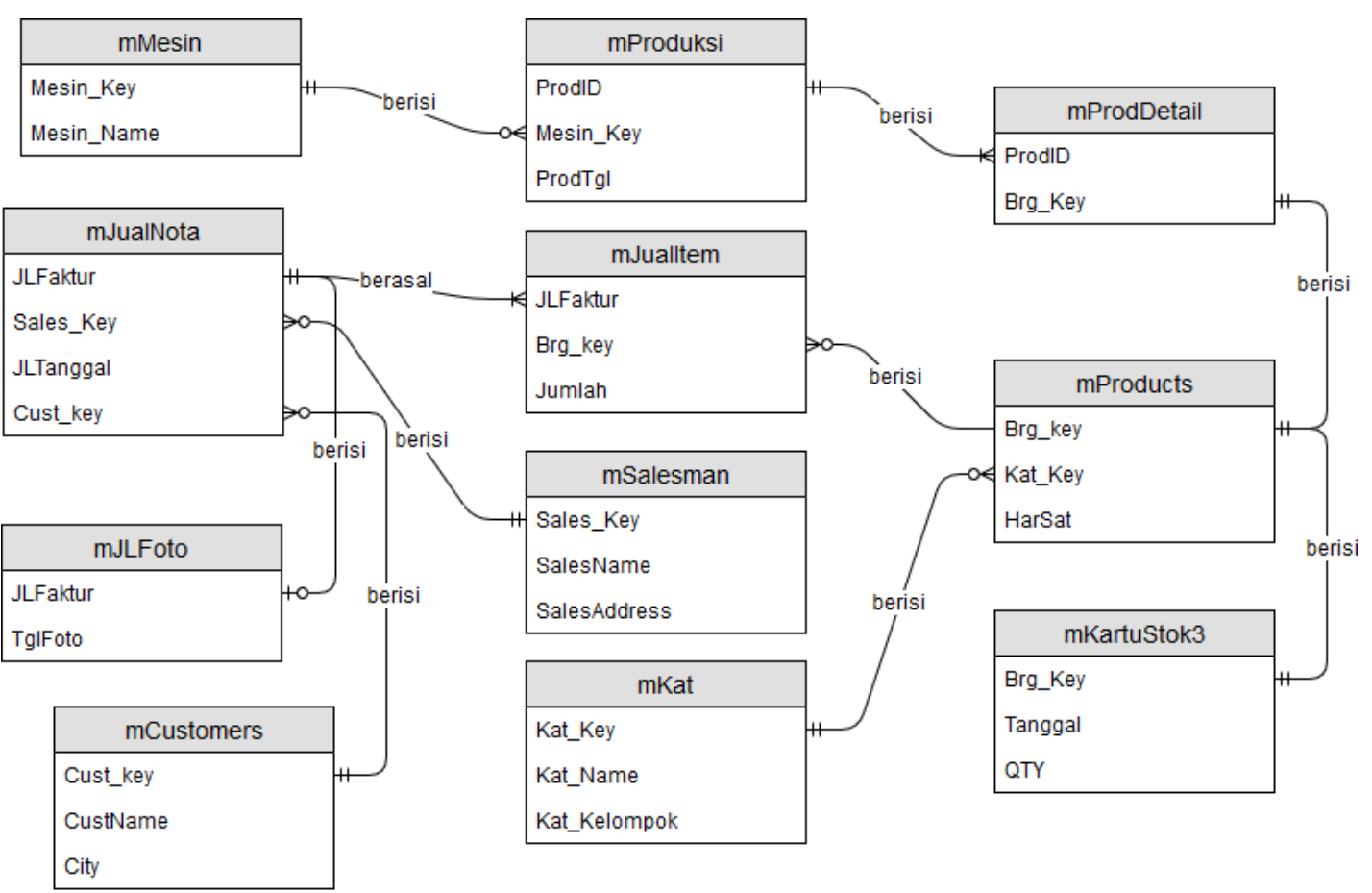

Gambar 6. Entity Relationship Diagram pada MSSQL

\section{Hasil dan Analisis}

Pengujian dilakukan dengan cara menguji fungsi-fungsi pada aplikasi dengan OS (Operating System) yang berbeda dan menguji aplikasi menggunakan jaringan internet.

User Interface pada aplikasi yang dirancang terbagi menjadi 4 bagian, yaitu Login Activity, MainMenu Activity, SubMenu Activity dan Function Menu Activity. Login Activity digunakan untuk keamanan aplikasi mobile supaya hanya bisa diakses oleh user yang memiliki id dan password. MainMenu Activity berfungsi untuk menghubungkan antar Activity yang ada pada aplikasi mobile. SubMenu Activity berfungsi untuk memberikan filter pada fungsi yang ingin dijalankan. Sedangkan Function Menu Activity berfungsi untuk melihat data yang melalui grafik, melihat data bukti retur berupa foto. 

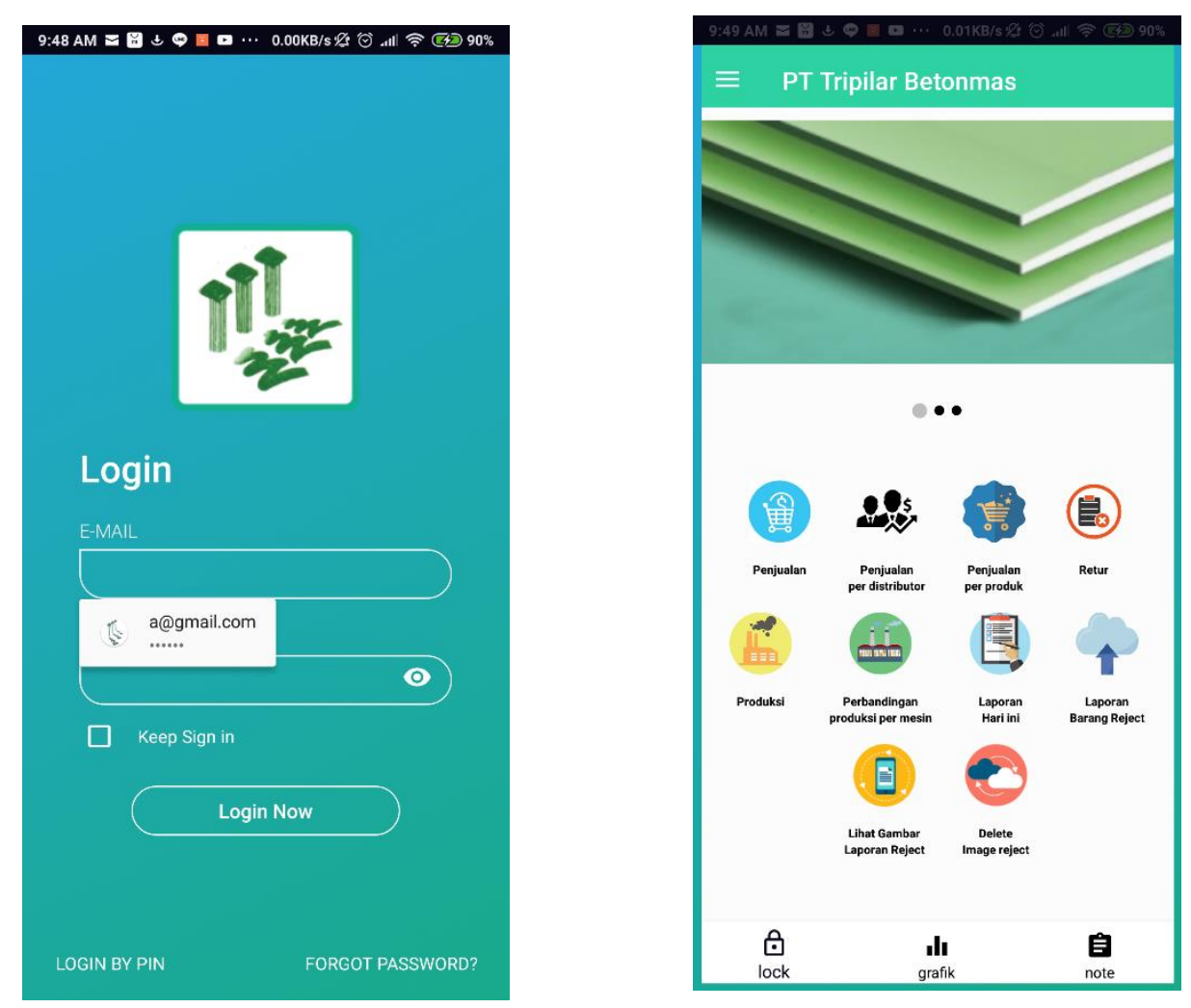

(a)

(b)

Gambar 7. a. User Interface Login Activity b. User Interface Main Menu Activity

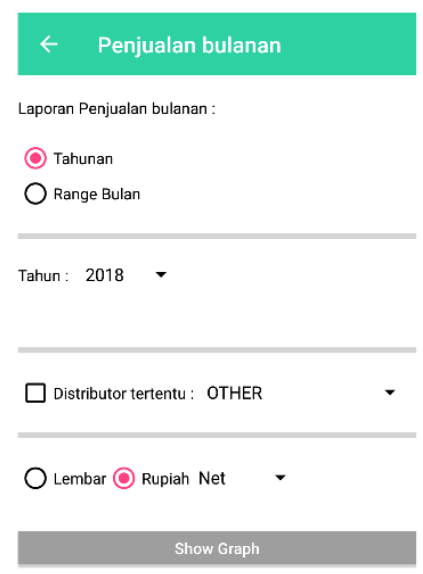

Gambar 8. User Interface Sub Menu Activity 


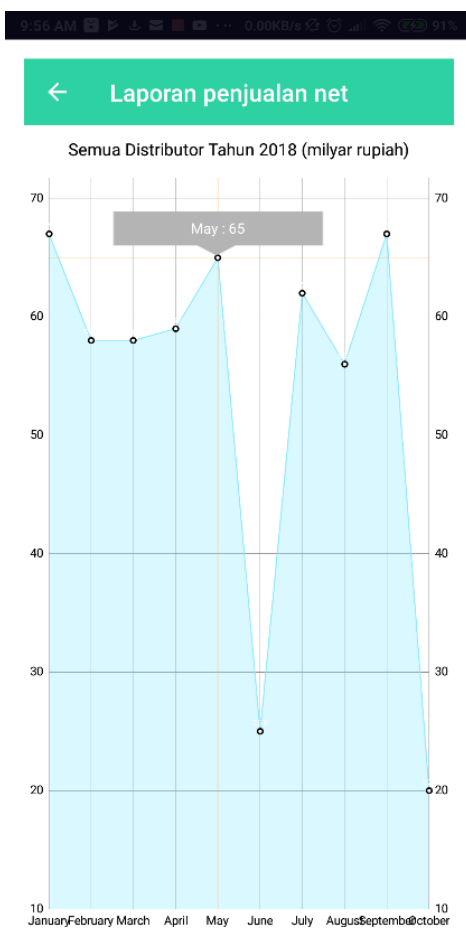

(a)

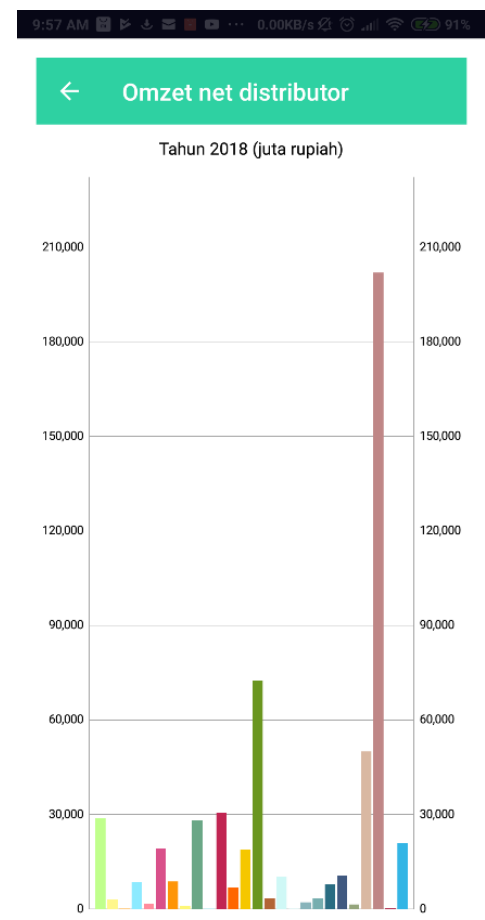

(b)

Gambar 9. a. User Interface Function Menu Activity Line Chart, b. User Interface Function Menu Activity Bar Chart

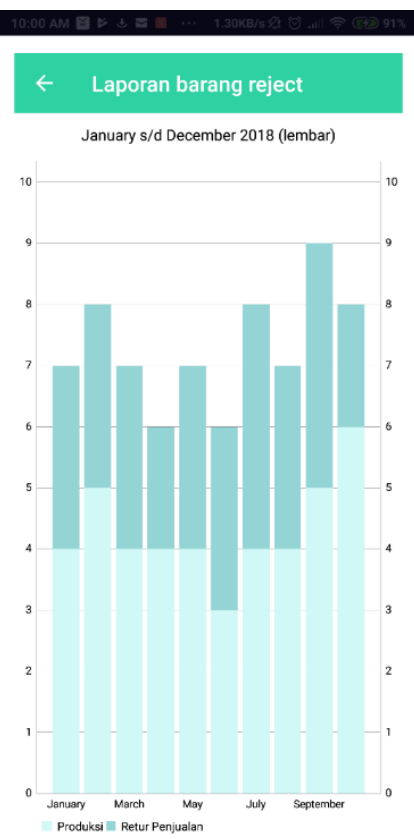

(a)

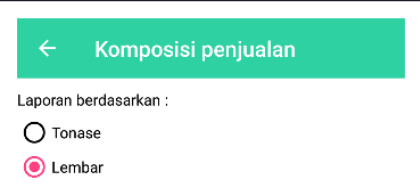

Semua Distributor Bulan May Tahun 2018

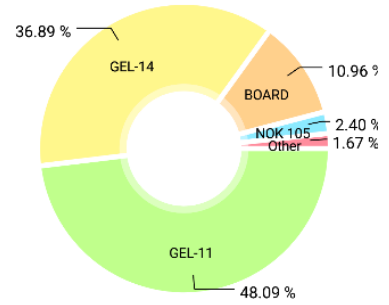

| GE-11 $=$ GE-14 $=$ BOARD $\mid$ || NOK 105 || Other

(b)

Gambar 10. a. User Interface Function Menu Activity Stackable Bar Chart, b. User Interface Function Menu Activity Pie Chart 


\begin{tabular}{l}
$\leftarrow \quad$ Search Nota \\
J0218/09/0003 \\
\hline$J 2518 / 09 / 0002$ \\
\hline$J 2818 / 10 / 0001$ \\
\hline$J 3118 / 09 / 0002$ \\
\hline$J 3318 / 09 / 0222$ \\
\hline$J 3318 / 09 / 0223$ \\
\hline
\end{tabular}
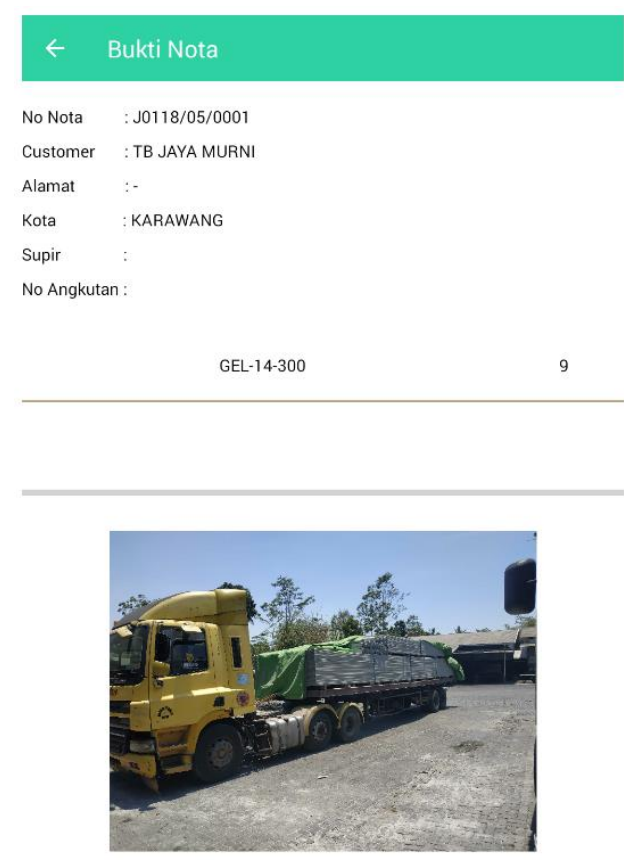

(b)

Gambar 11. a. User Interface Sub Menu Activity Search Nota, b. User Interface Function Menu Activity Retur

Pada pengujian dibawah ini menggunakan metode pengujian blackbox, yang bertujuan untuk menemukan fungsi-fungsi yang tidak benar. Pada pengujian kompatibilitas, aplikasi dijalankan pada OS Jelly Bean - Oreo untuk dapat mengetahui kompatibilitas aplikasi. Pengujian dilakukan dengan menjalankan aplikasi pada OS Jelly Bean - Oreo dengan menjalankan semua fungsi pada aplikasi.

Tabel 2. Hasil Pengujian Operating System

\begin{tabular}{|c|c|c|}
\hline Operating System & Error & Device \\
\hline Jelly Bean & $\begin{array}{c}\text { Fingerprint authentication \& mengambil gambar untuk bukti retur } \\
\text { menggunakan kamera }\end{array}$ & $\begin{array}{c}\text { Emulator } \\
\text { menggunakan kamera }\end{array}$ \\
\hline KitKat & $\begin{array}{c}\text { Fingerprint authentication \& mengambil gambar untuk bukti retur } \\
\text { menggunakan kamera }\end{array}$ & Emulator \\
\hline Lollipop & $\begin{array}{c}\text { Fingerprint authentication \& mengambil gambar untuk bukti retur } \\
\text { Marshmallow }\end{array}$ & Path penyimpanan data default URI file:// \\
\hline Nougat & Path penyimpanan data default URI file:// & Redmi 5 plus \\
\hline Oreo & Xiaomi Redminote 5 \\
\hline
\end{tabular}

Pengujian jaringan dilakukan untuk menguji jaringan yang digunakan untuk menjalankan aplikasi menggunakan Internet. Pengujian dilakukan dengan cara melakukan fungsi - fungsi yang ada pada aplikasi. 
MoBI, Sistem Informasi berbasis Android Baktiar Krisna Mukti Nugroho, Handoko, Hartanto Kusuma Wardana

Tabel 3. Hasil Pengujian Pengambilan Data Berupa Text

\begin{tabular}{|c|c|c|}
\hline Percobaan & $\begin{array}{c}\text { Menggunakan jaringan Wifi } \\
\text { (Indihome) } 400 \mathrm{~Kb} / \mathrm{s}\end{array}$ & $\begin{array}{c}\text { Menggunakan Operator selular } \\
\text { (Indosat)200Kb/s }\end{array}$ \\
\hline 1 & $4 \mathrm{~s}$ & $7 \mathrm{~s}$ \\
\hline 2 & $3 \mathrm{~s}$ & $9 \mathrm{~s}$ \\
\hline 3 & $5 \mathrm{~s}$ & $4 \mathrm{~s}$ \\
\hline 4 & $4 \mathrm{~s}$ & $5 \mathrm{~s}$ \\
\hline 5 & $2 \mathrm{~s}$ & $6 \mathrm{~s}$ \\
\hline 6 & $5 \mathrm{~s}$ & $7 \mathrm{~s}$ \\
\hline 7 & $4 \mathrm{~s}$ & $9 \mathrm{~s}$ \\
\hline 8 & $3 \mathrm{~s}$ & $5 \mathrm{~s}$ \\
\hline 9 & $5 \mathrm{~s}$ & $4 \mathrm{~s}$ \\
\hline 10 & $2 \mathrm{~s}$ & $7 \mathrm{~s}$ \\
\hline
\end{tabular}

Tabel 3 menunjukkan waktu yang dibutuhkan aplikasi untuk mengambil data penjualan. Waktu yang dibutuhkan berbeda-beda tergantung dari koneksi Internet yang digunakan, hal ini dipengaruhi konektivitas dari setiap operator penyedia layanan internet.

Tabel 4. Pengujian Jaringan Mengunggah dan Mengunduh Gambar

\begin{tabular}{|c|c|c|c|c|}
\hline \multirow{2}{*}{ Ukuran Gambar } & \multicolumn{2}{|c|}{ Waktu Mengunduh Gambar (s) } & \multicolumn{2}{c|}{ Waktu Mengunggah Gambar (s) } \\
\cline { 2 - 5 } & Wifi (indihome) & Indosat & Wifi (indihome) & Indosat \\
\hline $100 \mathrm{~kb}$ & 21 & 42 & 18 & Gagal \\
\hline $200 \mathrm{~kb}$ & 35 & 57 & 27 & Gagal \\
\hline $300 \mathrm{~kb}$ & 47 & Gagal & 59 & Gagal \\
\hline $400 \mathrm{~kb}$ & 58 & Gagal & Gagal & Gagal \\
\hline $500 \mathrm{~kb}$ & Gagal & Gagal & Gagal & Gagal \\
\hline $600 \mathrm{~kb}$ & & & & \\
\hline
\end{tabular}

Jaringan Wifi Indihome memiliki kecepatan up to $400 \mathrm{~kb} / \mathrm{s}$ dan jaringan seluler (Indosat) memiliki kecepatan up to $200 \mathrm{~kb} / \mathrm{s}$ pada Tabel 4. Semakin tinggi kecepatan jaringan yang digunakan akan semakin tinggi pula tingkat keberhasilan mengunduh ataupun mengunggah gambar.

\section{Kesimpulan}

Operating system Jelly Bean hingga Lollipop belum memiliki fitur fingerprint authentication, sehingga untuk fitur fingerprint authentication hanya bisa dijalankan setelah operating system Marshmallow. Aplikasi yang dirancang dapat berjalan dari OS Jelly Bean hingga Oreo. Pengambilan data pada aplikasi ini berupa JSON dan aplikasi dapat menyimpan ataupun mengunduh gambar pada aplikasi yang telah dirancang. Pada proses pengujian, semakin besar data yang ingin diambil maka waktu yang dibutuhkan semakin lama untuk memprosesnya. 


\section{Daftar Pustaka}

[1] Mobile Operating System Market Share Worldwide, [online]. http://gs.statcounter.com/os-market-share/mobile/worldwide. [Diakses pada 7 Oktober 2018]

[2] Burnette, Ed, Hello, Android(4 ${ }^{\text {th }}$ edition) Introducing Google's Mobile Development Platfrom, 2015.

[3] Petkovic, Dusan, Microsoft SQL Server 2016: A Beginner's Guide, Sixth Edition, 2016.

[4] Developer Android, [online]. https://developer.android.com/guide/ components/activities/activity-lifecycle_[Diakses pada 3 Juni 2018]

[5] Firebase, [online]. https://firebase.google.com/?hl=id. [Diakses pada 9 Juni 2018]

[6] Firebase Realtime Database, [online]. https://firebase.google.com/docs/database/?hl=id. [Diakses pada 9 Juni 2018]

[7] Firebase Authentication, [online]. https://firebase.google.com/docs/auth/?hl=id. [Diakses pada 9 Juni 2018]

[8] Ari- Koponen, Pekka. A Secure OAuth 2.0 Implementation Model, 2016.

[9] Sam Ruby, Leonard Richardson, RESTful Web Services, 2007. 